\title{
EFEKTIVITAS PENGGUNAAN THREAD LIFT DENGAN METODE JIN'S 3 NEEDLE PADA OVERWEIGHT
}

\author{
Listina Ade Widya Ningtyas, Sri Widyastari, Kurnia Eka Putri \\ Kementerian Kesehatan Politeknik Kesehatan Surakarta Jurusan Akupuntur
}

\begin{abstract}
Thread Lift Method, 3 Jinn Needles, Obesity. Excess body weight, normal weight, with waist circumference of $80-87 \mathrm{~cm}$ and BMI $\geq 23.0$. Jin's 3-Needle is a method of acupuncture therapy using three dots. Thread Lifts on acupuncture points can increase the body's metabolism. The purpose of this study to determine the effectiveness of Thread Therapy Using Methods Jin's 3 Needle in patients Overweight. Pretest Experimental Design Postest Control Group. The research location is at SMP N 2 Colomadu in March-June 2017. The population is teachers and employees in SMPN 2 Colomadu which is 60 people. Dependent variable decreased waist circumference and BMI, variable. Thread with Jin's 3 Needle method. Samples of 33 people with purposive sampling technique. Data analysis in this study using unpaired T Test. The result showed that the average BMI before therapy was $27,15 \mathrm{~kg} / \mathrm{m}^{2}$ and after therapy 26,71 $\mathrm{kg} / \mathrm{m}^{2}$ (CI: 0,29 -0,60), with standard deviation 0,434. Average waist circumference results before therapy was $96.79 \mathrm{~cm}$ and after therapy $93.62 \mathrm{~cm}$ (CI: 2.40-3.93), with a standard deviation of 2.160. After the test, $p$ value $0.001<0.05$ where Ho is rejected and Ha accepted. How to lift it with Jin's 3 Needle is effectively used on overweight.
\end{abstract}

Keywords: Thread Lift Method, 3 Jinn Needles, Obesity

Abstrak: Metode Thread lift, Jin's 3 Needle, Overweight. Kelebihan berat badan merupakan kondisi berat badan tubuh melebihi berat badan normal, dengan ukuran lingkar pinggang 80-87 cm dan BMI $\geq 23,0$. Jin's 3-Needle merupakan metode terapi akupunktur menggunakan tiga titik. Thread Lift pada titik akupunktur dapat meningkatkan metabolisme tubuh. Tujuan penelitian ini untuk mengetahui Efektifitas Penggunaan Terapi Thread lift dengan menggunakan Metode Jin's 3 Needle pada pasien Overweight. Jenis penelitian ini Experimental Pretest Postest Control Group Designs. Lokasi penelitian di SMP N 2 Colomadu pada bulan Maret-Juni 2017. Populasinya adalah guru dan karyawan di SMPN 2 Colomadu yaitu 60 orang. Variabel dependen penurunan lingkar pinggang dan BMI, variabel independen Thread Lift dengan metode Jin's 3 Needle. Sampel sebanyak 33 orang dengan teknik purposive sampling. Analisa data pada penelitian ini menggunakan Uji T tidak berpasangan. Hasil penelitian didapatkan nilai rata-rata BMI sebelum terapi $27,15 \mathrm{~kg} / \mathrm{m}^{2}$ dan setelah terapi $26,71 \mathrm{~kg} / \mathrm{m}^{2}$ (CI: 0,29 -0,60), dengan standar deviasi 0,434. Sedangkan hasil nilai ratarata lingkar pinggang sebelum terapi $96,79 \mathrm{~cm}$ dan setelah terapi 93,62 cm (CI: 2,403,93 ), dengan standar deviasi 2,160. Setelah dilakukan uji, $p$ value $0,001<0,05$ dimana Ho ditolak dan Ha diterima. Metode Thread lift dengan Jin's 3 Needle efektif digunakan pada overweight.

Kata Kunci : Metode Thread lift, Jin's 3 Needle, Overweight 


\section{PENDAHULUAN}

Overweight didefinisikan sebagai kondisi ketidakseimbangan dari akumulasi lemak yang berlebih pada jaringan adiposa, yaitu pada daerah perut maupun daerah lain seperti paha dan lengan. Akumulasi lemak pada daerah perut lebih sering terjadi dan dapat mengakibatkan munculnya resiko penyakit, bahkan menyebabkan kematian (Queensland Government, 2010). Berbagai macam penyakit yang dapat muncul akibat adanya overweight meliputi diabetes tipe 2 , penyakit jantung, hipertensi, stroke, dan dapat juga menyebabkan kanker. Overweight menjadi masalah yang sangat kompleks, karena dapat menimbulkan masalah sosial dan kejiwaan pada pasien yang mengalami obesitas atau overweight (Puska, 2003).

Hasil penelitian yang dilakukan National Health and Nutrition Examination Survey (NHANES) pada tahun 2007-2008 dengan menggunakan ukuran berat badan dan tinggi badan mengindikasikan bahwa sekitar 34,2\% masyarakat di Amerika Serikat pada usia dewasa $\geq 20$ th mengalami overweight, $33,8 \%$ masyarakat mengalami obesitas dan $5,7 \%$ mengalami obesitas yang berlebihan. Sedangkan pada tahun 20092010 data dari NHAHES menyatakan lebih dari $2 / 3$ usia dewasa yang mengalami overweight yaitu sekitar 68,8\%, sedangkan $1 / 3$ usia dewasa yang mengalami obesitas yaitu 35,7\% (Ogden, 2010).

Data prevalensi di Indonesia dan Amerika tidak berbeda jauh dalam hal peningkatan jumlah overweight. Penelitian proporsi overweight di DKI tahun 2006 tercatat $67 \%$ warga beresiko mengalami obesitas dan kelebihan berat dan 95\% wanita mengalami lingkar pinggang diatas normal (Sulistianingsih, 2012). Hasil Riset Kesehatan Dasar (Riskesdas) Indonesia tahun pada tahun 2010 menunjukkan bahwa 17,5\% jumlah orang dewasa di Indonesia termasuk kategori overweight, sedangkan tahun 2010 menunjukkan peningkatan sebesar 21,7\% (Neraca, 2012). Perkembangan kasus overweight di Indonesia berdasarkan NSS-HKI dari tahun 1999-2001 hasil data yang didapatkan pada laki-laki sekitar 14,9\%, sedangkan pada wanita $24 \%$ dan peningkatan dari tahun ke tahun lebih banyak terajdi pada wanita disbanding laki-laki (Atmarita, 2005).

Berdasarkan data diatas overweight perlu mendapatkan penanganan terapi khusus, karena terjadi peningkatan setiap tahunnya. Terapi yang digunakan pada kasus overweight sangat bervariasi diantaranya berupa diet, olah raga, penggunaan obat pelangsing, bahkan dengan terapi akupunktur. Terapi akupunktur sendiri memiliki berbagai macam metode untuk menangani kasus overweight, diantaranya dengan metode kurapunktur, thread lift maupun Jin's 3 Needle (Hamid, 2012).

\section{METODE PENELITIAN}

Jenis penelitian ini adalah kuantitatif dengan design penelitian Experimental Pretest Postest Control Group Designs. Teknik pengambilan sampel dengan metode purposive sampling yaitu sebanyak 33 orang. Analisa data yang digunakan pada penelitian ini menggunakan Uji $\mathrm{T}$ tidak berpasangan. Hal ini dapat dilakukan untuk mengetahui perbedaan hasil pengukuran lingkar pinggang dan BMI obyek sebelum dan sesudah terapi thread lift dengan metode Jin's Three Neddle. 
Analisa data penelitian menggunakan program SPSS 16.

\section{HASIL PENELITIAN}

1. Pembahasan Univariat

Hasil analisa data penelitian pada tabel 4.1 wanita dengan kelebihan berat badan didapatkan data distribusi usia yang ada adalah antara usia 46-65 tahun. Karakteristik sample penelitian ini paling banyak pada rentang usia 46-65 tahun sebanyak 28 orang dan sisanya terdiri dari usia 25-45 tahun 5 orang. Hal ini dimungkinkan sesuai dengan data pada tinjauan teori dimana kelebihan berat badan terutama dialami oleh wanita yang berusia > 45 tahun keatas yang tidak banyak aktivitas tubuh dan lebih banyak mengkonsumsi kalori (Xu Bin dan Liu Zhi-cheng, 2007). Pada rentang usia $>45$ tahun perlu adanya penanganan khusus untuk dapat mengurangi resiko terjadinya kelebihan berat badan, karena pada usia tersebut mulai terjadi penurunan metabolisme tubuh dan ditambah dengan adanya pola hidup yang tidak sehat serta menjadi pemicu munculnya penyakit kronis (Tomarere, 2011 dalam Candrawati, 2011).

Hasil analisa didapatkan data terbanyak sample penelitian adalah perempuan. Hal ini sesuai dengan tinjauan teori dimana wanita yang tidak banyak aktivitas tubuh dan lebih banyak mengkonsumsi kalori lebih mudah terjadi penumpukan akumulasi lemak yang berlebih pada tubuh (Xu Bin dan Liu Zhicheng, 2007). Selain itu diperkuat pada penelitian yang dilakukan Kavouras pada tahun 2008 (dalam Candrawati, 2011) mengenai aktivitas fisik dengan lingkar pinggang melaporkan bahwa individu yang melakukan aktivitas olahraga secara teratur, paling sedikit 30-60 menit pe hari dalam lima hari cukup untuk mempertahankan atau menurunkan berat badan secara bermakna. Berdasarkan data yang ada sebagian besar sample wanita jarang melakukan olah raga dan lebih banyak menghabiskan waktunya untuk mengerjakan pekerjaan kantor atau rumah tangga. Penelitian lain yang dilakukan oleh Nurmalina (2011) menyatakan bahwa wanita pada usia produktif lebih banyak mengkonsumsi makanan dan cemilan dengan aktivitas fisik yang tidak begitu berat dibandingkan pada laki-laki. Sehingga pada kondisi yang demikian akan menyebabkan terjadinya penumpukan lemak dibagian tubuh.

\section{Pembahasan Bivariat}

Hasil analisa data pada tabel diatas didapatkan data yang diambil untuk mengetahui pengaruh terapi tanam benang dengan metode jin's 3 needle terhadap penurunan lingkar pingggang dan BMI pada klien overweight. Data yang didapat kemudian dianalisis secara statistik dengan menggunakan uji paired t test dan didapatkan bahwa ada pengaruh thread lift metode jin's 3 needle terhadap overweight. Hal ini dibuktikan dengan hasil statistik pada tabel di atas didapatkan adanya perbedaan nilai mean sebelum dengan sesudah terapi pada pengukuran lingkar pinggang dan BMI.

Hasil analisis bivariat diatas sesuai dengan studi kasus yang dilakukan oleh Tang pada tahun 2002 (dalam Xu and Liu, 2007) terhadap klien overweight dengan menggunakan thread lift metode Jin's 3 needle juga telah berhasil menurunkan lingkar pinggang (Xu and Liu, 2007). Hasil penelitian ini juga sesuai dengan teori bahwa thread lift khususnya Jin's 3 needle bisa menurunkan berat badan sehingga nilai lingkar pinggang dan BMI 
juga mengalami penurunan melalui pengaturan sistem endokrin. Jin's 3Needle untuk overweight adalah kombinasi dari titik CV 12 (Zhongwan), GB 26 (Daimai) dan ST 36 (Zusanli). Ketiga titik tersebut memiliki hubungan dengan sistem endokrin (Yuan and Liu, 2004). Hal tersebut juga diperkuat dengan penelitian yang dilakukan oleh Hui et al (2005) dalam White et al (2008) penusukan pada titik ST 36 (Zusanli) dapat mempengaruhi sistem limbik karena menurut Wilborn et al (2005) ada beberapa hormon, komponen genetik, dan faktor lain yang berpengaruh terhadap kelebihan berat badan.

Pada penelitian ini penggunaan thread lift pada titik akupunktur tertentu dimaksudkan untuk dapat meningkatkan pembakaran kalori pada sample, terbukti dari beberapa sample yang ada mengalami perubahan baik dari ukuran lingkar pinggang maupun BMI. Hal ini sesuai dengan teori Janto (2015) thread lift dapat meningkatkan metabolisme tubuh, mengurangi nafsu makan, dan juga melancarkan pembuangan toksin seperti feses. Selain itu akupuntur dengan thread lift juga dapat mengurangi kemampuan tubuh untuk membentuk lemak, meningkatkan pembakaran kalori dan juga melancarkan siklus menstruasi. Pada hasil penelitian ini perubahan lingkar pinggang setelah dilakukan thread lift dengan metode Jin's 3 Needle antara $84 \mathrm{~cm}$ dan tertinggi $125 \mathrm{~cm}$. Pada teori lingkar pinggang orang Asia pada wanita dikatakan mengalami kelebihan berat badan apabila berukuran antara $80-87 \mathrm{~cm}$ ( Howel, 2012). Meskipun demikian pada penelitian ini sudah ada perubahan lingkar pinggang sebelum dan setelah dilakukan terapi yaitu antara $2-8 \mathrm{~cm}$. Pada beberapa sample tidak ada perubahan lingkar pinggang karena berbagai macam faktor, yaitu faktor asupan makanan yang dikonsumsi dan aktivitas sehari-hari.

$$
\text { Pada penelitian lain yang }
$$
dilakukan oleh Hamid et al (2012) menyatakan bahwa akupunktur dengan kombinasi diet efektif menuunkan berat badan dan mengurangi faktor resiko munculnya penyakit kronis. Dari data diatas disimpulkan bahwa terapi thread lift dengan metode Jin's 3 Needle dapat menurunkan lingkar pinggang, bahkan menurunkan BMI dan faktor resiko terjadinya penyakit kronis akibat overweight. Pada penelitian ini hasil pengukuran BMI setelah dilakukan terapi paling rendah $23 \mathrm{~kg} / \mathrm{m}^{2}$ dan tertinggi 33 $\mathrm{kg} / \mathrm{m}^{2}$. Perubahan BMI pada penelitian ini yaitu ada sample yang mengalami penurunan $1 \mathrm{~kg} / \mathrm{m}^{2}$ dan ada penambahan 1 $\mathrm{kg} / \mathrm{m}^{2}$. Meskipun demikian ada 3\% sample yang mengalami penambahan BMI sebanyak $1 \mathrm{~kg} / \mathrm{m}^{2}$ pada pengukuran lingkar pinggang mengalami pengurangan ukuran lingkar pinggang. Jadi dapat disimpulkan dari penelitian ini meskipun ada 18,2\% sample ukuran BMI tidak mengalami perubahan, ukuran lingkar pinggang sample mengalami pengurangan setelah dilakukan terapi.

\section{PEMBAHASAN}

Pasien nyeri muskuloskeletal mengalami keluhan nyeri secara kambuhan. Hal ini biasanya diperberat ketika pasien melakukan aktivitas yang membutuhkan kekuatan lebih maupun ketika mengalami kelelahan. Berdasarkan pengalaman informan pasien nyeri muskuloskeletal nyeri dialami sejak beberapa tahun yang lalu, dan pasien sudah melakukan pengobatan ke beberapa sarana pelayanan kesehatan medis maupun alternatif tetapi keluhan belum 
teratasi secara tuntas. Pasien nyeri muskuloskeletal cenderung akan mengurangi aktivitas yang menyebabkan nyerinya semakin memberat, dan beralih dengan melakukan upaya-upaya untuk mengurangi keluhan yang dirasakan seperti dengan diolesi minyak penghangat maupun dipijat ringan.

Dari data tersebut sejalan dengan teori Model Kepercayaan Kesehatan (Hochbaum, 1958) bahwa kepercayaan kesehatan didasarkan pada 3 aspek yaitu adanya kesiapan individu merubah perilaku untuk menghindari penyakit maupun memperkecil resiko kesehatan, adanya dorongan dalam lingkungan individu untuk merubah perilaku dan perilaku itu sendiri. Selain itu faktor psikis pasien nyeri muskuloskeletal juga dapat dipengaruhi oleh karena kondisi kesehatan yang terganggu dalam jangka waktu lama dan bersifat kambuhan, sehingga pasien melakukan aktivitas sehari-hari tidak maksimal. Hal ini sesuai dengan teori yang disampaikan oleh Freund (1995) mengenai pengalaman sakit dari dimensi sosial kebudayaan meliputi gejala sakit yang dialami setiap orang dalam jangka waktu lama dapat menyebabkan kecemasan dan ketakutan yang luar biasa dari orang tersebut.

Sementara itu menurut Murti (2010 dalam Sulaeman, 2013) kesiapan individu dipengaruhi oleh persepsi mengenai kerentanan penyakit, potensi ancaman, motivasi untuk menekan kerentanan penyakit, dan adanya kepercayaan dengan adanya perubahan perilaku dapat memberikan keuntungan. Penelitian ini membuktikan bahwa pasien nyeri muskuloskeletal melakukan terapi akupunktur untuk mengurangi kerentanan penyakit dari nyeri muskuloskeletal yang dialami supaya tidak semakin menghambat aktivitas sehari-hari, apabila tidak teratasi dengan baik dapat memperparah kondisi fisik maupun psikis pasien serta mempengaruhi produktifitas dari pasien nyeri muskuloskeletal.

Adanya kepercayaan pasien nyeri muskuloskeletal dalam merubah perilaku yang tidak sehat dapat memberikan keuntungan terbebas dari nyeri yang dirasakan menjadi faktor predisposisi bagi pasien. Informan pasien nyeri muskuloskeletal percaya dengan mengikuti saran anjuran dari terapis dapat mengurangi keluhan nyeri yang dirasakan. Hal ini sesuai dengan teori yang disampaikan Green (1980) mengenai faktor yang mempengaruhi kepatuhan pasien, yaitu melalui pengetahuan yang dipahami seseorang akan muncul kepercayaan dan kepatuhan mengikuti saran yang disampaikan orang lain.

Adanya dukungan dari keluarga dan adanya sarana prasarana pengobatan Teori yang disampaikan Aderson (1968) dalam Health System Model menjadi alasan individu memanfaatkan fasilitas kesehatan yang ada. Dari data tersebut dapat di analisis bahwa pasien sebagai individu dalam memanfaatkan fasilitas kesehatan yang ada berdasarkan faktor belum adanya fasilitas kesehatan di sekitar tempat tinggalnya dan sarana prasarana kesehatan yang kurang memadai antara satu tempat dengan tempat lainnya.

Berbagai usaha pencarian pengobatan yang dilakukan pasien nyeri muskuloskeletal sangat beragam yaitu mulai dari pengobatan secara mandiri, datang ke pengobatan tradisional dibandingkan pengobatan medis, dan melakukan pengobatan ke fasilitas kesehatan yang ada sesuai dengan saran tenaga medis (Sanduzzi et al., 2014). Kondisi seperti ini sering sekali terjadi 
didalam masyarakat, terutama untuk beberapa kasus yang sifatnya kambuhan. Kebanyakan pasien datang melakukan terapi karena sudah mengeluhkan nyeri selama 1-3 tahun yang lalu dan bersifat kambuhan, serta sebelumnya sudah melakukan berbagai pengobatan untuk mengurangi keluhan yang dirasakan.

Kondisi sakit kronis yang dialami pasien nyeri muskuloskeletal tidak lepas dari adanya usaha pencarian pelayanan kesehatan, dari Theory Health System Model (Aderson, 1968) dari data yang didaptkan bahwa faktor predisposing demografi dan struktur sosial pasien yang sebelumnya pernah melakukan terapi akupunktur dan sembuh, serta munculnya keyakinan terhadap pelayanan kesehatan terapi akupunktur di RS Ja'far Medika Karanganyar dapat mengurangi keluhan yang dirasakan. Sedangkan dari faktor enabling dukungan dana dari keluarga serta pembiayaan terapi yang terjangkau maupun sarana prasarana terapi akupunktur yang memadai di RS Ja'far Medika Karanganyar. Faktor need yaitu kebutuhan akan kesehatan dan permintaan pelayanan kesehatan dapat mempengaruhi model pengguna pelayanan kesehatan pasien nyeri muskuoskeletal di RS Ja'far Medika Karanganyar.

Perubahan perilaku yang terjadi tidak bisa lepas dari adanya proses perubahan sikap dan komunikasi yang baik. Komunikator dalam proses perubahan perilaku harus memiliki kredibilitas yang tinggi, rasa suka terhadap suatu hal yang sama atau persamaan persepsi, dan dianggap memiliki status yang sama dengan pendengar (Kholid, 2012). Berdasarakan hasil wawancara mendalam dengan informan pasien nyeri muskuloskeletal adanya komunikasi yang baik dari terapis dalam pelayanan kesehatan, dapat mempercepat proses kesembuhan pasien. Selain itu dengan adanya perhatian dan rasa empati yang tinggi dari terapis kepada pasien dapat mempermudah terapis dalam mendapatkan informasi dari pasien dan sekaligus memberikan saran anjuran yang sesuai dengan kondisi pasien.

Komunikasi terapetik yang baik dapat mempermudah terapis untuk melakukan penatalaksanaan terapi, sehingga dapat meningkatkan kepercayaan dan keyakinan pasien kepada terapis. Hal ini sesuai dengan pernyataan Priyoto (2014) bahwa pelaksanan program pelayanan kesehatan diperlukan adanya suatu komunikasi antara tenaga kesehatan sebagai komunikator dan pasien atau masyarakat sebagai komunikan.

Menurut Northouse (1998) dalam proses komunikasi dapat terjadi pertukaran informasi baik verbal maupun non verbal, langsung maupun tidak langsung, personal maupun kelompok mengenai masalah kesehatan yang ada. Komunikasi non verbal dalam pelayanan kesehatan sering dilakukan oleh pemberi layanan kesehatan kepada pasien melalui kontak badan, proksimitas (kedekatan antar perorangan), postur, penampilan fisik, ekspresi wajah, gerakan tangan dan kepala, arah pandang dan kontak mata.

Proses komunikasi kesehatan menurut Northouse (1998) terjadi antara pelaku kesehatan dan masyarakat berkaitan dengan permasalahan kesehatan serta faktor - faktor yang berpengaruh didalamnya. Dalam hasil penelitian ini peneliti mendapatkan fenomena mengenai proses komunikasi terapetik yang dilakukan oleh terapis akupunktur terhadap pasien nyeri muskuloskeletal, yang berpengaruh terhadap kesembuhan 
pasien tersebut. Pemberi layanan kesehatan yang istimewa akan melengkapi usaha tersebut dengan pelayanan yang melampaui harapan pasien yang dikenal sebagai service excellent (Basuki, 2008).

Ahli sosiologi medis seperti Stacey (1976 dalam Bury dan Jonathan, 2004) berpendapat bahwa sifat pasien sebagai konsumen terkadang tidak memiliki kemampuan untuk memilih, hal ini karena kekurangan pengetahuan mengenai kondisi yang sedang dialami dan bagaimana pengobatannya. Sehingga dalam hal ini diperlukan adanya kerja sama yang baik dari tenaga kesehatan untuk dapat menyampaikan informasi sejelas mungkin sesuai dengan kebutuhan pasien sebagai seorang konsumen (Bury, Michael dan Jonathan Gabe. 2004).

\section{KESIMPULAN DAN SARAN}

1. Dari hasil distribusi karakteristik responden berdasarkan besar lingkar pinggang sebelum dilakukan thread lift didapatkan data maksimum $85 \mathrm{~cm}$ dan minimum $131 \mathrm{~cm}$, dengan ratarata $96,79 \mathrm{~cm}$.

2. Dari hasil distribusi karakteristik responden berdasarkan besar lingkar pinggang sesudah dilakukan thread lift didapatkan data maksimum $84 \mathrm{~cm}$ dan minimum $125 \mathrm{~cm}$, dengan ratarata $93,62 \mathrm{~cm}$.

3. Dari hasil distribusi analisa didapatkan data perubahan sesudah dilakukan thread lift metode Jin's 3 Needle dengan nilai maksimum $8 \mathrm{~cm}$ dan minimum $0 \mathrm{~cm}$, dan rata-rata terjadi penurunan lingkar pinggang sebanyak $3,17 \mathrm{~cm}$.

4. Dari hasil distribusi karakteristik responden berdasarkan besar BMI sebelum dilakukan thread lift didapatkan data maksimum $23 \mathrm{~kg} / \mathrm{m}^{2}$ dan minimum $33 \mathrm{~kg} / \mathrm{m}^{2}$, dengan ratarata $27,15 \mathrm{~kg} / \mathrm{m}^{2}$.

5. Dari hasil distribusi karakteristik responden berdasarkan besar BMI sesudah dilakukan thread lift didapatkan data maksimum $23 \mathrm{~kg} / \mathrm{m}^{2}$ dan minimum $33 \mathrm{~kg} / \mathrm{m}^{2}$, dengan ratarata $26,71 \mathrm{~kg} / \mathrm{m}^{2}$.

6. Dari hasil distribusi analisa didapatkan data perubahan BMI sesudah dilakukan thread lift metode Jin's 3 Needle dengan nilai maksimum $1 \mathrm{~kg} / \mathrm{m}^{2}$ dan minimum -1 $\mathrm{kg} / \mathrm{m}^{2}$, dan rata-rata terjadi penurunan lingkar pinggang sebanyak 0,45 $\mathrm{kg} / \mathrm{m}^{2}$.

7. Dari hasil analisa diatas menunjukkan ada pengaruh terapi thread lift metode Jin's 3 Needle pada overweight.

\section{DAFTAR RUJUKAN}

Atmarita. 2005. Nutrition Problem in Indonesia. The Article An Integrated International Seminar and Workshop on Lifestyle-Related Diseases Gajah MAda University

Hamid Abdi. 2012. The Effects of Body Acupuncture on Obesity: Anthropometric Parameters, Lipid Profile, and Inflammatory and Immunologic Marker. The Scientific World Journal Volume 201211 pages.

Janto, Ari. 2015. PengertianTanamBenang (tanambenang.com/prosedurkecantikan-akupuntur-tanambenang/)

Howel, Denise. 2012. Waist Circumference and Abdominal Obesity among Older Adult:Patterns, Prevalence and Trends. Journal Plos One

Nurmalina R, Valley B. Pencegahan dan manajemen obesitas. PT Elex 
Media Komputindo Kelompok Gramedia - Jakarta; 2011; h.4-5, 1,22,131-132,16.

Ogden Cynthia L. \& Carroll Margaret D. 2010. Prevalence of Overweight, Obesity, and Extreme Obesity Among Adults: United States, Trends 1960-1962 Through 20072008. National Center of Health Statistics. 1-2

P.Puska, C.Nishida, D.Porter. 2003. Obesity and Overweight. World Health Organization

Queensland Government. 2010. Obesity. Queensland Maternity and Neonatal Clinical Guidelines Program

$\mathrm{Xu}$ Bin, Liu Zhi-cheng, Han Chou-ping. 2007. Acupuncture for Weight Loss. Shanghai Scientific and Technical Publishers 